\title{
Insecticidal activity of four medicinal plant powders and extracts against Angoumois grain moth, Sitotroga cerealella (Olivier) [Lepidoptera: Gelechidae]
}

\section{Ileke $K D^{*}$}

Department of Environmental Biology and Fisheries, Faculty of Science, Adekunle Ajasin University, P.M. B. 001, Akungba - Akoko, Ondo State, Nigeria.

\begin{abstract}
Powders and extracts prepared from Capsicum frutescens, Cymbopogon citratus, Moringa oleifera, Anacardium occidentale were tested for their insecticidal potential against Angoumois grain moth, Sitotroga cerealella. The powder of $C$. frutescens had the highest mortality rate of $100 \%$ after 2 days of application at all tested concentrations. The extracts killed all the adult moths introduced at all tested concentrations. The survival of the moth from egg to adult when treated with the plant powders showed significantly greater mortality. Extracts of all the tested plants were toxic to adult moths and also prevent hatching of the eggs of $S$. cerealella..
\end{abstract}

Keywords: mortality, hatchability, adult emergence

\section{Introduction}

Wheat(Triticum sp) is a cereal grain originating from the Levant region of the Near East and Ethiopian Highlands, but now cultivated worldwide (Belderok et al. 2000). It is grown on more land area than any other commercial crop and is the most important staple food for humans, used to make flour for leavened, flat and steamed breads, biscuits, cookies, cakes, breakfast cereal, pasta, noodles, couscous and for fermentation to make beer (Neil 2002) and other alcoholic beverages or biofuel (Cauvain\& Cauvain 2003).

Wheat is attacked by various insect pests between harvest and storage. The most economically important insect pests of stored wheat are the granary weevils(Sitophilus granarius), maize weevils(Sitophilus zeamais), rice weevils(Sitophilus oryzae), lesser grain borer(Rhyzopertha dominica), larger grain borer(Prostephanus truncatus), Angoumois grain moth(Sitotroga cerealella), Indian meal moth(Plodia interpunctella), rice moth(Corcyra cephalonica) and red flour beetle(Tribolium castaneum) (Adedire 2001; Ileke 2011). S. cerealella has been known as a primary, serious and injurious pest of wheat in the Angoumois province of France since 1736; it is now cosmopolitan in distribution, particularly in the tropics and the warm temperate regions (Adedire 2001). It is a good flier and this enhances easy crossinfestation.

Despite success in controlling insect pests using synthetic insecticides, there have been several setbacks such as high mammalian toxicity, high level of persistence in the environment, health hazards, toxic residues on food, adverse effects on non-target organisms and pest resistance as well as toxic effect to the users (Ileke \& Oni 2011). These issues have necessitated the use of other control measures with little or no negative impacts on the environment and not toxic to mammals (Ileke 2008). One solution would be to replace synthetic chemicals with compounds that occur naturally in plants (Adedire \& Lajide 2003; Ileke et al. 2012). Vegetable oils, plant powders and extracts have been used to reduce postharvest losses of cereals and grain legumes (Odeyemi 1998; Adedire \& Lajide, 1999; Ofuya et al. 2007; Nwaubani \& Fasoranti 2008). So far, many reports of deterrent activity of plant products on stored product insects have been focused on beetle pests (Lale 1992; Ashamo \& Akinnawonu 2012), and very few on moths (Ashamo 2010). This work investigated the insecticidal activity of four medicinal plant powders and oils againstS. cerealella in stored

* Author for correspondence: tel +2348034318706email : kayodeileke@yahoo.com 
wheat grains. These plants have been reported to be effective in protecting cowpea seeds from infestation by cowpea bruchidCallosobruchus maculatusand maize weevilSitophilus zeamais(Oparaeke \& Bunmi 2006; Oni 2011; Adedire et al. 2011; Ileke \& Olotuah 2012).

\section{Materials \& Methods}

The starter culture of $S$. cerealella used for this study was obtained from infested wheat grains(Triticum aestivum, variety 'hard red winter') in a warehouse in Akure (Ondo State, Nigeria), and reared on uninfested grains cleaned of foreign matter, disinfested by keeping in a freezer at $-5^{\circ} \mathrm{C}$ for 7 days and then air-driedand stored in plastic containers with tight lids disinfested by swabbing with $90 \%$ ethanol.All the life stages of the moth, particularly the eggs, are very sensitive to cold. Moths and grains were placed in 2-litre Kilner jars, covered with muslin cloth and placed in an insect-rearing cage. The cage legs were placed in Petri dishes filled with water to which a few drops of kerosene were added to prevent access of predatory ants. Cultureswere renewed with healthy fresh uninfested wheat grains, as necessary, and the culture and experiment were maintained at ambient temperature of $28 \pm 2{ }^{\circ} \mathrm{C}$ and $75 \pm 5 \%$ relative humidity.

Some of the plant products used were purchased from the local markets in Akungba Akoko, Ondo State, Nigeria. The main criterion for selecting the plants was that they are edible and form an important part of the diet of Nigerians. The plants included the fruit of the Chilli Pepper Capsicum frutescens, the stem of Lemon Grass Cymbopogon citratus, the seed of the Drum Stick Tree Moringa oleifera andthe seed of the Cashew Anacardium occidentale. The nuts of A. occidentalewere sun-dried for seven days to allow for safe and easy cracking to remove the nuts without crushing them. The remaining plant products were rinsed in clear water to remove sand and other impurities, and cut into smaller pieces before being air-dried in the laboratory and pulverised into a fine powder using a blender (Supermaster $₫$, Model SMB 2977, Japan). The powders were further sieved to pass through $1-\mathrm{mm}^{2}$ perforations. The powders were then packed in specimen bottles with tight lids and stored in a refrigerator at $4^{0} \mathrm{C}$ prior to use.

The plant powders were thoroughly mixed with $20 \mathrm{~g}$ of wheat grains in $250-\mathrm{ml}$ plastic containers using 0.0 (untreated), $0.5,1$ and $2 \mathrm{gms}$. The containers with their contents were gently shaken to ensure thorough admixture of the wheat grains and treatment powders. Twenty teneral (unsexed) adultS. cerealella were randomly selected and introduced to each of the containers. Four replicates of the treatments and untreated controls were laid out in a Complete Randomized Design. Mortality of the adult S. cerealella was assessed after every $24 \mathrm{~h}$ during the $96 \mathrm{~h}$ of treatment. On the fifth day, all insects, both dead and alive, were removed from each container. Twenty days after infestation with adult $S$. cerealella, the containers were check daily for adult emergence and recorded. Similarly, twenty (0-24 h old) eggs of $S$. cerealella were introduced into $10 \mathrm{~g}$ of treated wheat grains using the above concentrations. The jars were observed daily and the number of adults emerging from each treatment was recorded.

Extracts of $C$. frutescens, $C$. citratus, M. oleifera and A. occidentalepowders were carried out using a cold-extraction method. About $150 \mathrm{~g}$ of powder was soaked in an extraction bottle containing $100 \%$ methanol for 72 hours, stirring occasionally. Filtration was carried out using a double layer of Whatman No. 1 filter papers, and the methanol evaporated using a rotary evaporator at $30-40^{\circ} \mathrm{C}$ with a rotary speed of 3-6 rpm for 8 hours. The resulting extract was then air-dried to remove traces of solvent. From this stock solution, different extract concentrationsin methanol of $1 \%, 2 \%$ and $3 \%$ were prepared in $10-\mathrm{ml}$ aliquots.

Extracts of $C$. frutescens, $C$. citratus, $M$. oleifera and $A$. occidentale at rate of $1 \mathrm{ml}$ of each concentration $(1 \%, 2 \%$ and $3 \%$ ) were mixed with $20 \mathrm{~g}$ of clean wheat grains in 250 - 
mlplastic containers. The extracts were thoroughly mixed with the aid of a glass rod and agitated for 5-10 min to ensure uniform coating. The containers were left open for $30 \mathrm{~min}$ so as to allow traces of methanol to evaporate. A control experiment was also set up without solvent or extract. Twenty unsexed teneral adultS. cerealella were randomly selected and introduced to each of the containers and covered. Four replicates of the treatments and untreated controls were laid out in Complete Randomized Design. Twenty days after infestation with adult $S$. cerealella, the containers were checked daily for adult emergence and recorded.

In another experiment, $1 \mathrm{ml}$ of each extract was spread on 9-cm-diameter filter paper inside a Petri dish and allowed to stay for a few minutes. Twenty (0-24 h old) eggs of $S$. cerealella were then introduced on top of the filter paper, replicated four times. The percentage hatchability and adult emergence were determined.

Data were subjected to Analysis of Variance and where significant differences existed, treatment means were separated using the Tukey's Test.

\section{Results}

All powders showed moth mortality, ranging from $61.3 \%$ - 100\% (Table 1). Adult moth mortality increased as the concentration of the powders and length of exposure increased. Capsicum frutescens powder was the most effective, causing $100 \%$ mortality of moth after two days of exposure at all concentrations. This was followed by A. occidentales powder, that evoked $100 \%$ mortality of $S$. cerealella after three days of application at all tested concentrations. Moringa oleifera powder was the least toxic, failing to kill all moths even at the highest concentration and after four days of application.Table 2 shows the effect of plant powders on subsequent emergence of adult moths from this experiment. Significantly more $S$. cerealellasubsequently emerged as adults from the untreated control than the other treated wheat grains. No adults emerged from wheat grains treated with $C$. frutescens and $A$. occidentales powders, while some emerged from C. citratus and M. oleiferatreatments. Adult emergence reduced with increasing concentration of powders.

\begin{tabular}{|c|c|c|c|c|c|c|c|c|c|}
\hline \multirow{2}{*}{ Plant powder } & \multirow{2}{*}{$\begin{array}{c}\text { dose } \\
(\mathrm{g})\end{array}$} & \multicolumn{8}{|c|}{ Exposure time (days), mean \pm S. E. } \\
\hline & & 1 & & 2 & & 3 & & 4 & \\
\hline \multirow[t]{3}{*}{ C. frutescens } & 0.5 & $61.3 \pm 2.4$ & f & $100.0 \pm 0.0$ & $\mathrm{~g}$ & $100.0 \pm 0.0$ & $\mathrm{e}$ & $100.0 \pm 0.0$ & $\mathrm{~d}$ \\
\hline & 1.0 & $80.0 \pm 4.6$ & $\mathrm{~g}$ & $100.0 \pm 0.0$ & $\mathrm{~g}$ & $100.0 \pm 0.0$ & $\mathrm{e}$ & $100.0 \pm 0.0$ & $\mathrm{~d}$ \\
\hline & 2.0 & $100.0 \pm 0.0$ & $\mathrm{~h}$ & $100.0 \pm 0.0$ & $\mathrm{~g}$ & $100.0 \pm 0.0$ & $\mathrm{e}$ & $100.0 \pm 0.0$ & $\mathrm{~d}$ \\
\hline \multirow[t]{3}{*}{ M. oleifera } & 0.5 & $10.0 \pm 4.6$ & $\mathrm{~b}$ & $36.3 \pm 1.4$ & $\mathrm{~b}$ & $47.5 \pm 1.4$ & $\mathrm{~b}$ & $61.3 \pm 2.4$ & $\mathrm{~b}$ \\
\hline & 1.0 & $21.3 \pm 2.4$ & bc & $48.8 \pm 1.3$ & bcd & $56.3 \pm 1.2$ & $\mathrm{~b}$ & $76.3 \pm 1.2$ & $\mathrm{c}$ \\
\hline & 2.0 & $45.0 \pm 2.0$ & de & $57.5 \pm 4.6$ & de & $77.5 \pm 1.4$ & $\mathrm{~b}$ & $97.5 \pm 4.6$ & d \\
\hline \multirow[t]{3}{*}{ C. citratus } & 0.5 & $17.5 \pm 1.4$ & $\mathrm{~b}$ & $41.3 \pm 2.4$ & $\mathrm{bc}$ & $56.3 \pm 1.2$ & $\mathrm{~b}$ & $73.3 \pm 3.2$ & $\mathrm{c}$ \\
\hline & 1.0 & $33.3 \pm 3.2$ & $\mathrm{~cd}$ & $52.5 \pm 3.2$ & cde & $72.5 \pm 3.2$ & $\mathrm{c}$ & $95.0 \pm 4.1$ & d \\
\hline & 2.0 & $52.5 \pm 3.2$ & ef & $61.3 \pm 3.4$ & ef & $88.8 \pm 1.3$ & $\mathrm{~d}$ & $100.0 \pm 0.0$ & d \\
\hline \multirow[t]{3}{*}{ A. occidentale } & 0.5 & $31.3 \pm 2.4$ & $\mathrm{c}$ & $68.8 \pm 5.2$ & $\mathrm{f}$ & $100.0 \pm 0.0$ & $\mathrm{e}$ & $100.0 \pm 0.0$ & $\mathrm{~d}$ \\
\hline & 1.0 & $52.5 \pm 3.2$ & ef & $85.0 \pm 4.1$ & $\mathrm{f}$ & $100.0 \pm 0.0$ & $\mathrm{e}$ & $100.0 \pm 0.0$ & $\mathrm{~d}$ \\
\hline & 2.0 & $61.3 \pm 2.4$ & $\mathrm{f}$ & $100.0 \pm 0.0$ & $\mathrm{~g}$ & $100.0 \pm 0.0$ & $\mathrm{e}$ & $100.0 \pm 0.0$ & d \\
\hline Control & 0.0 & $0.0 \pm 0.0$ & $\mathrm{a}$ & $0.0 \pm 0.0$ & $\mathrm{a}$ & $0.0 \pm 0.0$ & $\mathrm{a}$ & $0.0 \pm 0.0$ & $\mathrm{a}$ \\
\hline
\end{tabular}

Table 1: Percentage mortality of Sitotroga cerealella adults treated with plant powders (dose per $20 \mathrm{~g}$ wheat). Means \pm s.e., $\mathrm{n}=4$ replicates. Means within the same column followed by the same letter(s) are not significantly different at $\mathrm{P}>0.05$ using Tukey's test. 


\begin{tabular}{|c|c|c|c|}
\hline & \multicolumn{3}{|c|}{ Concentration (g per $20 \mathrm{~g}$ wheat) } \\
\hline Plant powder & $0.5 \mathrm{~g}$ & $1.0 \mathrm{~g}$ & $2.0 \mathrm{~g}$ \\
\hline C. frutescens & $0.0 \pm 0.0 \quad \mathrm{a}$ & $0.0 \pm 0.0 \mathrm{a}$ & $0.0 \pm 0.0 \mathrm{a}$ \\
\hline M. oleifera & $21.3 \pm 2.4 \mathrm{~b}$ & $16.3 \pm 1.2 \mathrm{~b}$ & $12.5 \pm 3.2 b$ \\
\hline C. citratus & $19.3 \pm 1.6 \mathrm{~b}$ & $14.4 \pm 0.7 b$ & $7.5 \pm 1.4 \mathrm{~b}$ \\
\hline A. occidentale & $0.0 \pm 0.0 \mathrm{a}$ & $0.0 \pm 0.0 \mathrm{a}$ & $0.0 \pm 0.0 \mathrm{a}$ \\
\hline Control & $45.0 \pm 2.5 \mathrm{c}$ & $45.0 \pm 2.5 \mathrm{c}$ & $45.0 \pm 2.5 \mathrm{c}$ \\
\hline
\end{tabular}

Table 2: Effect of plant powders on numbers of emergingadult Sitotroga cerealella from the experiment of Table 1 . Means \pm s.e., $n=4$ replicates. Letters as in Table 1, using Tukey's test

When eggs were introduced on treated wheat grains, significantly $(\mathrm{P}<0.05)$ more adult emergence was recorded in the control than treated samples (Table 3). The number of adult emergence were lower in wheat treated with $C$. frutescens and A. occidentales.

\begin{tabular}{|c|c|c|c|c|c|c|}
\hline & \multicolumn{6}{|c|}{ Concentration (g per $10 \mathrm{~g}$ wheat) } \\
\hline Plant Powder & 0.5 & & 1.0 & & & \\
\hline C. frutescens & $12.5 \pm 1.4$ & $\mathrm{a}$ & $7.5 \pm 1.6$ & $\mathrm{a}$ & $3.3 \pm 3.2$ & $\mathrm{a}$ \\
\hline M. oleifera & $28.8 \pm 1.3$ & $\mathrm{~b}$ & $19.2 \pm 1.2$ & $\mathrm{a}$ & $11.3 \pm 2.4$ & $\mathrm{a}$ \\
\hline C. citrates & $17.5 \pm 1.6$ & $\mathrm{ab}$ & $13.3 \pm 3.2$ & $\mathrm{a}$ & $7.5 \pm 1.6$ & $\mathrm{a}$ \\
\hline A. occidentals & $15.0 \pm 4.1$ & a & $9.2 \pm 1.2$ & $\mathrm{a}$ & $4.6 \pm 1.3$ & $\mathrm{a}$ \\
\hline Control & $71.3 \pm 2.4$ & $\mathrm{~b}$ & $71.3 \pm 2.4$ & $\mathrm{~b}$ & $71.3 \pm 2.4$ & $\mathrm{~b}$ \\
\hline
\end{tabular}

Table 3: Survival (\% adult emergence from 20 eggs) of Sitotroga cerealella eggs treated with plant powders.Mean \pm s.e., $\mathrm{n}=4$ replicates. Letters as in Table 1,using Tukey's test

Treatment with plant extracts caused extensive adult mortality (Table 4). The oils from $C$. frutescens and A. occidentales caused $100 \%$ mortality of S. cerealella within 24 hours of application. All extracts were able to cause $100 \%$ mortality after two days of application apart from $M$. oleifera.

\begin{tabular}{|c|c|c|c|c|c|c|c|c|}
\hline \multirow[t]{2}{*}{ Plant powder } & \multirow{2}{*}{$\begin{array}{c}\text { Conc. } \\
(\%)\end{array}$} & \multicolumn{7}{|c|}{ Exposure time (days) } \\
\hline & & 1 & 2 & & 3 & & 4 & \\
\hline \multirow[t]{3}{*}{ C. frutescens } & 1 & $100.0 \pm 0.0 \mathrm{~d}$ & $100.0 \pm 0.0$ & $\mathrm{c}$ & $100.0 \pm 0.0$ & $\mathrm{~b}$ & $100.0 \pm 0.0$ & $\mathrm{~b}$ \\
\hline & 2 & $100.0 \pm 0.0 \mathrm{~d}$ & $100.0 \pm 0.0$ & $\mathrm{c}$ & $100.0 \pm 0.0$ & $\mathrm{~b}$ & $100.0 \pm 0.0$ & b \\
\hline & 3 & $100.0 \pm 0.0 \mathrm{~d}$ & $100.0 \pm 0.0$ & $\mathrm{c}$ & $100.0 \pm 0.0$ & $\mathrm{~b}$ & $100.0 \pm 0.0$ & $\mathrm{~b}$ \\
\hline \multirow[t]{3}{*}{ M. oleifera } & 1 & $70.0 \pm 4.6 \quad b$ & $86.3 \pm 1.2$ & $\mathrm{~b}$ & $100.0 \pm 0.0$ & $\mathrm{~b}$ & $100.0 \pm 0.0$ & $\mathrm{~b}$ \\
\hline & 2 & $88.8 \pm 1.3 \mathrm{~cd}$ & $100.0 \pm 0.0$ & $\mathrm{c}$ & $100.0 \pm 0.0$ & $\mathrm{~b}$ & $100.0 \pm 0.0$ & $\mathrm{~b}$ \\
\hline & 3 & $100.0 \pm 0.0 \mathrm{~d}$ & $100.0 \pm 0.0$ & $\mathrm{c}$ & $100.0 \pm 0.0$ & $\mathrm{~b}$ & $100.0 \pm 0.0$ & $\mathrm{~b}$ \\
\hline \multirow[t]{3}{*}{ C. citratus } & 1 & $81.3 \pm 2.4 b c$ & $100.0 \pm 0.0$ & $\mathrm{c}$ & $100.0 \pm 0.0$ & $\mathrm{~b}$ & $100.0 \pm 0.0$ & $\mathrm{~b}$ \\
\hline & 2 & $96.3 \pm 1.2 \mathrm{~d}$ & $100.0 \pm 0.0$ & $\mathrm{c}$ & $100.0 \pm 0.0$ & $\mathrm{~b}$ & $100.0 \pm 0.0$ & $\mathrm{~b}$ \\
\hline & 3 & $100.0 \pm 0.0 \mathrm{~d}$ & $100.0 \pm 0.0$ & $\mathrm{c}$ & $100.0 \pm 0.0$ & $\mathrm{~b}$ & $100.0 \pm 0.0$ & $\mathrm{~b}$ \\
\hline \multirow[t]{3}{*}{ A. occidentales } & 1 & $100.0 \pm 0.0 \mathrm{~d}$ & $100.0 \pm 0.0$ & $\mathrm{c}$ & $100.0 \pm 0.0$ & $\mathrm{~b}$ & $100.0 \pm 0.0$ & $\mathrm{~b}$ \\
\hline & 2 & $100.0 \pm 0.0 \mathrm{~d}$ & $100.0 \pm 0.0$ & $\mathrm{c}$ & $100.0 \pm 0.0$ & $\mathrm{~b}$ & $100.0 \pm 0.0$ & $\mathrm{~b}$ \\
\hline & 3 & $100.0 \pm 0.0 \mathrm{~d}$ & $100.0 \pm 0.0$ & $\mathrm{c}$ & $100.0 \pm 0.0$ & $\mathrm{~b}$ & $100.0 \pm 0.0$ & b \\
\hline Control & 0 & $0.0 \pm 0.0$ & $0.0 \pm 0.0$ & $\mathrm{a}$ & $0.0 \pm 0.0$ & $\mathrm{a}$ & $0.0 \pm 0.0$ & $\mathrm{a}$ \\
\hline
\end{tabular}

Table 4: Effect of plant oils on mortality of adult Sitotroga cerealella. Mean \pm s.e., $n=4$ replicates. Letters as in Table 1, using Tukey's test.

There was no adult emergence from wheat grains treated with $C$. frutescens and $A$. occidentales extracts at all tested concentrations(Table5). The results obtained from the 
hatchability of eggs and subsequent adult emergence showed that oils from $C$. frutescens and A. occidentales were effective in killing the eggs of $S$. cerealella (Table 6).

\begin{tabular}{lrcr}
\hline & \multicolumn{3}{c}{ Concentration } \\
\hline Extract & \multicolumn{1}{c}{$1 \%$} & $2 \%$ & $3 \%$ \\
\hline C. frutescens & $0.0 \pm 0.0 \mathrm{a}$ & $0.0 \pm 0.0 \mathrm{a}$ & $0.0 \pm 0.0 \mathrm{a}$ \\
M. oleifera & $3.3 \pm 3.2 \mathrm{~b}$ & $0.8 \pm 1.3 \mathrm{~b}$ & $0.0 \pm 0.0 \mathrm{a}$ \\
C. citrates & $1.3 \pm 2.4 \mathrm{~b}$ & $0.5 \pm 1.4 \mathrm{~b}$ & $0.0 \pm 0.0 \mathrm{a}$ \\
A. occidentales & $0.0 \pm 0.0 \mathrm{a}$ & $0.0 \pm 0.0 \mathrm{a}$ & $0.0 \pm 0.0 \mathrm{a}$ \\
Control & $45.0 \pm 2.5 \mathrm{c}$ & $45.0 \pm 2.5 \mathrm{c}$ & $45.0 \pm 2.5 \mathrm{c}$ \\
\hline
\end{tabular}

Table 5: Effect of plant oils on adult emergence of Sitotroga cerealella. Mean \pm s.e., $\mathrm{n}=4$ replicates. Letters as in Table 1 , using Tukey's test.

\begin{tabular}{crr}
\hline Plant extract & \% Hatchability & \% Adult emergence \\
\hline C. frutescens & $17.5 \pm 1.4 \mathrm{a}$ & $0.0 \pm 0.0 \mathrm{a}$ \\
M. oleifera & $52.5 \pm 3.2 \mathrm{~b}$ & $9.2 \pm 1.2 \mathrm{~b}$ \\
C. citratus & $40.0 \pm 4.1 \mathrm{~b}$ & $4.3 \pm 2.4 \mathrm{~b}$ \\
A. occidentales & $16.3 \pm 1.2 \mathrm{a}$ & $0.0 \pm 0.0 \mathrm{a}$ \\
Control & $71.3 \pm 2.4 \mathrm{c}$ & $67.5 \pm 1.4 \mathrm{c}$ \\
\hline
\end{tabular}

Table 6: Effect of plant oils on eggs of Sitotroga cerealella. Mean \pm s.e., $\mathrm{n}=4$ replicates, each replicate of 20 eggs. Letters as in Table 1, using Tukey's test.

\section{Discussion}

The present study showed that powders and extracts from $C$. frutescens, $C$. citratus, $M$. oleifera and A.occidentale were very effective in suppressing S. cerealella. The insecticidal potential of these plants depended on the format and concentration applied. Capsicum frutescens powder and extract were especially quick and effective, reducing oviposition, hatchability and suppressing adult emergence. These observed activities may be its pungency, attributed to the presence of capsacin (Miyakado et al., 1979; Oni 2011; Ashamo \& Akinnawo, 2012).

The powder and oil of $A$. occidentales was also very toxic to the survival of $S$. cerealella: no adults emergedfrom eggs treated with oil. Many researchers have reported the insecticidal and ovicidal effects of $A$. occidentales extract against Callosobruchus species (Oparaeke \& Bunmi 2006; Adedire et al. 2011; Ileke \& Olotuah 2012). The mode of action could be that the powder or extract coat the treated wheat grains, preventing contact between the grains and adult moth, leading to starvation. The powder and oil can also block the spiracles, leading to suffocation, as suggested by Adedire et al.(2011). This insecticidal activity has been linked to the presence of anacardic acid and cardanol (Adedire et al. 2011; Ileke \& Olotuah, 2012).

$M$. oleifera also reduced the survival and development of $S$. cerealella. Toxicity of $M$. oleifera extract on survival and adult emergenceof $C$. maculatus has beenreported by Mbailo et al. (2006). Ileke \&Oni (2011) reported the toxicity of M. oleifera seed powder in reducing the longevity of Sitophilus zeamais on stored wheat grains.

This study has also shown that treating wheat grains with $C$. citratus powder and oil are toxic to $S$. cerealella, again reducing adult emergence. Dike \& Mbah (1992) reported the powder as effective against $C$. maculatus. The plant is characteristicallyaromatic, with a repellent effect (Oparaeke \&Dike, 1996).

Our results justifythe use of powder and extract of $C$. capsicum, M. oleifera, C. citratus and $A$. occidentalesas plant-derived insecticides against $S$. cerealella. Since adult $S$. cerealella do not feed on food commodities, but only visit to deposit their eggs, the use of oviposition 
inhibitors would be advantageous for the management of this lepidopteran pest. The powder and extract of these plants could be mixed with stored grains before storage in order to prevent attack by this secondary insect pest. The availability of these plants, their non-toxicity to man or other mammals, the fact that they are eco-friendly, their medicinal value and their potential as biopesticides make them candidates for upgrading traditional post-harvest protection practices in sub-Saharan Africa.

\section{Acknowledgements}

The author is grateful to Mr. Jegede Olaniyi, the Technologist in the Chemistry Research Laboratory, Department of Chemistry \& Industrial Chemistry, Adekunle Ajasin University, Akungba Akoko, Ondo State, Nigeria for his technical assistance during the extraction processes.

\section{References}

Adedire CO (2001) Biology, ecology and control of insect pests of stored grains. Dave Collins publication, Nigeria.

Adedire CO\& Lajide L (1999) Toxicity and oviposition deterrence of some plant extracts on cowpea storage bruchid, Callosobruchus maculatus. Journalof Plant Diseases \& Protection 106: 647 - 653

Adedire CO \& Lajide L (2003) Ability of extract of ten tropical plant species to protect maize grains against infestation by the maize weevil Sitophilus zeamais during storage. Nigerian Journal of Experimental Biology 4(2): 175-179

Adedire CO, Obembe OO, Akinkurolele RO \& Oduleye O (2011) Response of Callosobruchus maculatus (Coleoptera: Chysomelidae: Bruchinae) to extracts of cashew kernels. Journalof Plant Diseases \& Protection 118(2):75 - 79

Ashamo MO (2010) Management of the yam moth, Dasyses rugosella, a pest of stored yam tubers using plant products. $10^{\text {th }}$ International Working Conference on Store Product Protection. $793-798$.

Ashamo MO \& Akinnawonu O (2012) Insecticidal efficacy of some plant powders and extracts against the Angoumois moth, Sitotroga cerealella (Olivier) [Lepidoptera: Gelechiidae]. Archives of Phytopathology \& Crop Protection, 45: 1051 - 8.

Belderok B, Hans M\& Dingena AD (2000) Bread making quality of wheat. Springer. pp. 3

Cauvain SP \& Cauvain PC (2003) Bread making. CRC Press. pp.540.

Ileke KD (2008) Insecticidal activity of five edible plants powders against lesser grain borer, Rhyzopertha dominica on stored sorghum grains. Science Research Annals 5(1): $72-80$

Ileke KD (2011) Effect of Sitophilus zeamais Mot. and S. oryzae (L.) [Coleoptera: Curculionidae] infestation on grain quality of wheat (Triticum aestivum). Journal of Physical \& Biological Science 4: 7-12.

Ileke KD \& Oni MO (2011) Toxicity of some plant powders to maize weevil, Sitophilus zeamais (Coleoptera: Curculionidae) on stored wheat grains. African Journal of Agricultural Research 6(13): 3043 - 3048.

Ileke KD \& Olotuah OF (2012) Bioactivity of Anacardium occidentales and Allium sativum powders and oils extracts against cowpea bruchid, Callosobruchus maculatus (Fab) [Coleoptera: Chrysomelidae]. International Journal of Biology 4(1): 96 - 103.

IlekeKD, Odeyemi OO \& Ashamo MO (2012) Insecticidal activity ofAlstonia boonei De Wild powder against cowpea bruchid, Callosobruchusmaculatus (Fab.) [Coleoptera : Chrysomelidae] in stored cowpea seeds. International Journal of Biology 4 (2): 125 - 131

Mbailao M, Nanadoum M, Automne B, Gabra B \& Emmanuel A (2006) Effect of six common seed oils on survival, egg lying and development of the cowpea weevil, Callosobruchus maculatus. Journal of Biological Science 6 (2): 420 - 425

Miyakado M, Nakayama I, Yoshoka H \& Nakatani NN (1979) The piperase amides: structure of piperacide, a new insecticide amide from Piper nigrum. Agricultural Biology \& Chemistry 43: 1609 - 1611

Neil R (2002) Booze: the drinks Bible for the $21^{\text {st }}$ century. Octopus Publishing Group-Cassell Illustrated. pp. 112

Nwaubani SI \& Fasoranti JO (2008) Efficacy of cow bone charcoal dust in the management of maize weevil, Sitophilus zeamaia and the lesser grain borer, Rhyzopertha dominica infesting stored maize grains. Nigerian Journal of Entomology 25: 15 - 25

Odeyemi OO (1998) Feeding and oviposition inhibiting action of powder extract of Aframomum melegueta on Corcyra cephalonica and Ephestia cautella. African Journal of Entomology 24: 98 - 106

Ofuya TI, Olotuah OF \& Aladesanwa RD (2007) Potential of dusts of Eugenia aromatic dry flower buds, and black pepper dry fruit formulated with three organic flours for controlling Callosobruchusmaculatus. Nigerian Journal of Entomology 24: 98 - 106

Oni MO (2011) Evaluation of seed and fruit powder of Capsicum annum and C. frutescens for control of Callosobruchus maculatus (Fab.) in stored cowpea and Sitophilus zeamais in stored maize. International Journal of Biology 3(2):185 - 188 
Oparaeke AM \& Dike MC (1996) Comparison of garlic and lemon grass products in the control of Callosobruchus maculatus onstored cowpea grains. Nigerian Journal of Entomology 13: 73 - 80

Oparaeke AM \& Bunmi OJ (2006) Insecticidal potential of cashew, Anarcadium occidentale for control of the beetle, Callosobruchus subinnotatus on bambara groundnut. Archives of Phytopathological \& Plant Protection 39(4): 247 - 251.

\section{الملخص العربي}

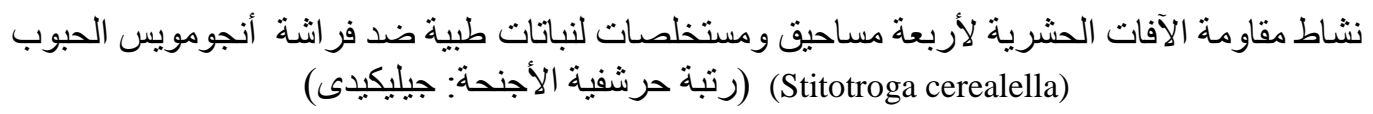

$$
\text { قُسم الأسماك و البيئة البيولوجية ـ كلية العلوم - جامعة أديكينلى أجاسين - ب م ب } 001 \text { ـ أكونجبا - و لاية أكوكو أونودو - نيجيريا }
$$

Capsicum frutescens, Cymbopogon citratus, Moringa oleifera, تم اختبار نأثير مساحيق ومستخلصات أربعة نباتات طبية وهى

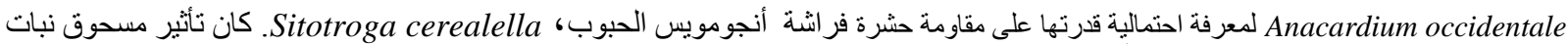

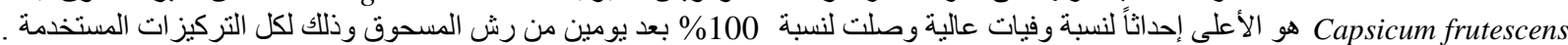

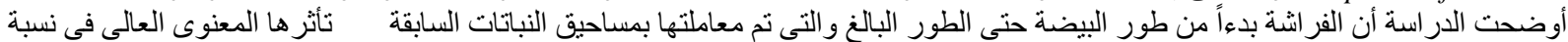
الوفيات. كانت مستخلصات جميع النباتات ذات تأثير سام للفر اشات الناضجة وأيضا منعت فقس البيض فى الفر اشة محل الدر اسة . 